\title{
Pengaruh Model Discovery Learning terhadap Keaktifan Siswa dalam Pembelajaran IPA Kelas IV SD YPK Persiapan Mirafan
}

\author{
Elda Martha Faan ${ }^{1}{ }$, Ahmad Yulianto $^{2} \&$ Asrul $^{3}$ \\ Program Studi PGSD, Universitas Pendidikan Muhammadiyah Sorong, Indonesia \\ $\bowtie$ E-mail: eldafaan@gmail.com
}

\begin{abstract}
Abstrak
Penelitian ini dilakukan dengan tujuan untuk mengetahui pengaruh model discovery learning terhadap keaktifan siswa dalam pembelajaran IPA kelas IV SD YPK Persiapan Mirafan. Penelitian ini merupakan penelitian eksperimen, dengan desain One-Shot Case Study. Populasi dalam penelitian ini adalah seluruh siswa SD YPK Persiapan Mirafan dengan sampel kelas IV yang berjumlah 10 siswa. Instrumen yang digunakan dalam penelitian adalah observasi dan instrumen angket keaktifan siswa. Data yang diperoleh pada penelitian selanjutnya diuji normalitas sebagai uji prasyarat untuk melakukan uji hipotesis. Uji hipotesis yang digunakan yaitu One Sampel T-Test. Berdasarkan hasil penelitian diketahui bahwa hasil uji One Sample T-Test diperoleh hasil thitung sebesar 12,984 nilai df pada penelitian $\mathrm{n}-1$ yaitu 10-1 $=9$, nilai df 9 adalah 2,262 jadi t hitung $>\mathrm{t}$ tabel yaitu 12,984 >2,262. Dari hasil uji one sampel t-test menunjukkan bahwa $\mathrm{H} 1$ diterima dan $\mathrm{H} 0$ ditolak artinya ada pengaruh model discovery learning terhadap keaktifan siswa dalam belajar. Maka kesimpulan penelitian ini adalah terdapat pengaruh model discovery learning terhadap keaktifan siswa dalam pembelajaran IPA kelas IV SD YPK Persiapan Mirafan.
\end{abstract}

Kata Kunci: Model Discovery Learning; Keaktifan Siswa; Pembelajaran IPA.

\begin{abstract}
This research was conducted with the aim to determine the effect of the discovery learning model on student activeness in the fourth grade science learning of SD YPK Preparation Mirafan. This research is an experimental study, with a One-Shot Case Study design. The population in this study were all students of SD YPK Preparation Mirafan with a sample of class IV totaling 10 students. The instruments used in the study were observation and student activity questionnaire instruments. The data obtained in subsequent studies were tested for normality as a prerequisite test for conducting hypothesis testing. The hypothesis test used is the One Sample T-Test. Based on the results of the study, it is known that the results of the One Sample T-Test showed that the t count was 12,984, the df value in the $n-1$ study was 10-1 = 9, the df 9 value was 2.262, so t count> t table namely 12,984> 2.262. From the results of the one sample $t$-test, it shows that $\mathrm{Hl}$ is accepted and $\mathrm{HO}$ is rejected, which means that the discovery learning model has an effect on student activity in learning. So the conclusion of this study is that there is an effect of discovery learning model on student activeness in science learning for grade IV SD YPK Preparation Mirafan.
\end{abstract}

Keywords: Discovery Learning Mode; Student Activity; Science Learning. 


\section{PENDAHULUAN}

Pendidikan merupakan salah satu usaha yang dilakukan untuk mencapai suatu tujuan tertentu. Melalui usaha yang dilakukan tersebut diharapkan dapat meningkatkan pengetahuan dan menggali potensi-potensi yang dimiliki oleh peserta didik sehingga dapat berguna untuk diri sendiri maupun untuk orang lain. Hal ini tertuang dalam Undang - Undang Republik Indonesia Nomor 20 tahun 2003 tentang Sistem Pendidikan Nasional pasal 1 ayat 1 yang menjelaskan bahwa: Pendidikan adalah usaha sadar dan terencana untuk mewujudkan suasana belajar dan proses pembelajaran agar peserta didik secara aktif mengembangkan potensi dirinya untuk memiliki kekuatan spiritual keagamaan, pengendalian diri, kepribadian, kecerdasan, akhlak mulia, serta keterampilan yang diperlukan dirinya, masyarakat, bangsa dan Negara.

Berdasarkan pengertian pendidikan yang tercantum dalam Undang- Undang tersebut, pendidikan sangatlah berpengaruh untuk mengembangkan sumber daya manusia yang berkualitas serta diperlukan dalam kehidupan bangsa dan negara demi kemajuan suatu bangsa dan negara. Ada tiga model pembelajaran yang diterapkan pada kurikulum 2013 yaitu model pembelajaran discovery learning, model pembelajaran berbasis masalah dan model pembelajaran berbasis proyek (Kurniasih dan Sani, 2014). Salah satu model yang digunakan dari ketiganya adalah model discovery learning. model ini dipilh karena dapat mengaktifkan siswa dalam belajar secara fisik maupun mental (Asrul, 2018). Model discovery learning merupakan komponen dari suatu bagian praktek pengajaran, yaitu suatu jenis mengajar yang meliputi metode-metode yang dirancang untuk meningkatkan rentangan keaktifan siswa yang lebih besar, berorientasi kepada proses, mengarahkan pada diri sendiri, mencari sendiri dan refleksi yang sering muncul sebagai kegiatan belajar.

Discovery adalah proses mental dimana siswa mampu mengasimilasikan sesuatu konsep atau prinsip. Proses mental yang dimaksud adalah mengamati, mencerna, mengerti, menggolong-golongkan, membuat dugaan, menjelaskan, mengukur, membuat kesimpulan dan sebagainya (Roestiyah, 2011: 20). Oleh sebab itu, dengan model discovery learning, siswa akan mampu menyimpan pengetahuan lebih lama dalam memorinya karena mereka menemukan sendiri jawabannya.

Pengetahuan yang tersimpan dalam memori diharapkan mampu menimbulkan nilai-nilai perilaku yang baik bagi anak dan dari perilaku yang baik itu, menjadi sebuah kebiasaan bagi anak dan menimbulkan keterampilan yang berguna bagi masyarakat lainnya. Ilmu Pengetahuan Alam (IPA) berhubungan dengan cara mencari tahu tentang alam secara sistematis, sehingga IPA bukan hanya penguasaan kumpulan pengetahuan yang berupa fakta-fakta, konsep-konsep, atau prinsipprinsip saja tetapi juga merupakan suatu proses penemuan (Wisudawati \& Sulistyowati, 2014).

Pembelajaran IPA sebaiknya dilaksanakan secara discovery learning untuk menumbuhkan kemampuan berpikir, bekerja dan bersikap ilmiah serta mengkomunikasikannya sebagai aspek penting kecakapan hidup. Oleh karena itu pembelajaran IPA di sekolah dasar menekankan pada pemberian pengalaman belajar secara langsung melalui penggunaan dan pengembangan keterampilan proses dan sikap ilmiah.

Hasil observasi lapangan yang dilakukan oleh peneliti terhadap sekolah dasar di SD YPK Persiapan Mirafan, nampak 
beberapa kekurangan seperti keterbatasan alat peraga, keadaan kelas yang tidak kondusif, dan model pembelajaran yang tidak bervariasi, menjadi salah satu penyebab perserta didik kurang aktif sehingga dan rendahnya motivasi belajar siswa. Siswa masih malu bertanya maupun memjawab pertanyaan yang diberikan guru. Berdasaekan data dokumentasi pada semester ganjil 2019/2020 bahwa hanya sekitar 61\% siswa kelas IV yang mencapai Kriteria Ketuntasan Minimal (KKM) pada mata pelajaran IPA.

Keaktifan belajar siswa masih rendah, terlihat dari kurangnya perhatian terhadap pelajaran, siswa belum mampu mengaitkan materi IPA dengan kehidupan sehari-hari, kurang percaya diri dan tingkat kepuasan masih rendah. Padahal motivasi merupakan faktor yang banyak berpengaruh terhadap proses dan hasil belajar siswa serta berguna untuk mencapai keberhasilan belajar siswa secara optimal. Penyebab lainnya adalah kemungkinan kurangnya penerapan model pembelajaran yang lebih bervariasi. Penguasaan terhadap model pembelajaran sangat diperlukan untuk memperoleh kesuksesan atau keberhasilan dalam mencapai tujuan pembelajaran. Jadi dengan model discovery learning, maka peneliti yakin akan mampu meningkatkan motivasi belajar siswa, tentunya akan berdampak pada keaktifan belajar dan keterampilan siswa yang juga meningkat.

\section{METODE PENELITIAN}

Jenis penelitian ini adalah penelitian Kuantitatif dengan metode eksperimen, adapun desian yang digunakan adalah berupa One-Shot Case Study. Pada penelitian eksperimen ini melakukan satu kali pengukuran di depan (pretest) sebelum adanya perlakuan (treatment), setelah itu melakukan pengukuran lagi (posttest).

Penelitian ini bertujuan untuk melihat keaktifan belajar siswa pada kelas eksperimen dengan menggunakan angket. Sebelum menerapkan Model Discovery Learning maka terlebih dahulu diberi pretest untuk mengetahui tingkat kemampuan awal siswa tersebut dan setelah pembelajaran tersebut diadakan posttest untuk melihat hasil akhir dari pembelajaran tersebut.

Populasi dalam penelitian ini adalah seluruh siswa SD YPK Persiapan Mirafan dengan sampel kelas IV yang berjumlah 10 siswa. Instrumen yang digunakan dalam penelitian adalah observasi dan instrumen angket keaktifan siswa. Data yang diperoleh pada penelitian selanjutnya diuji normalitas sebagai uji prasyarat untuk melakukan uji hipotesis. Uji hipotesis yang digunakan yaitu One Sampel T-Test.

\section{HASIL DAN PEMBAHASAN}

Sebelum dilakukan pengujian hipotesis untuk melihat sejauh mana pengaruh variable $\mathrm{X}$ terhadap Y maka terlebih dahulu dilakukan uji ahli instrument dan uji rliabilitas. Penelitian ini menggunakan instrumen penelitian berupa angket berjumlah 20 butir pernyataan. Sebelum angket diberikan kepada siswa di sekolah, terlebih dahulu dikonsultasikan dengan satu professional Judgment dosen PGSD FKIP UNIMUDA Sorong dengan cara dimintai pendapat tentang instrumen angket yang telah disusun oleh peneliti. Ahli tersebut menyatakan bahwa instrumen angket yang telah dibuat tersebut telah layak digunakan.

Uji reliabilitas digunakan untuk menguji kehandalan seluruh pernyataan penelitian yang tercantum pada kuisioner. Dengan total 20 butir pernyataan. Berdasarkan hasil uji reliabilitas menggunakan SPSS 16.0 for windows, maka 
dapat dijabarkan outputnya pada tabel dibawah ini:

Tabel 1. Ouptut Uji Reliabilitas Pre-Test

\begin{tabular}{rr}
\hline \multicolumn{2}{c}{ Reliability Statistics } \\
\hline Cronbach's Alpha & N of Items \\
.681 & 20 \\
\hline
\end{tabular}

Berdasarkan perhitungan uji reliabilitas terhadap instrumen pre test menggunakan SPSS V16.0 diperoleh hasil Cronbach's Alpha untuk instrumen angket pre test sebesar 0,681 dan nilai ini lebih besar dari alpha yaitu 0,5 dimana $0,681>0,6$. Dengan demikian, instrumen pre test tersebut telah memenuhi syarat reliabel dan dapat digunakan untuk penelitian.

Tabel 2.Ouptut Uji Reliabilitas Post-Test

\begin{tabular}{rr}
\hline \multicolumn{2}{c}{ Reliability Statistics } \\
\hline Cronbach's Alpha & N of Items \\
.773 & 20 \\
\hline
\end{tabular}

Berdasarkan perhitungan uji reliabilitas terhadap instrumen post test menggunakan SPSS V16.0 diperoleh hasil Cronbach's Alpha untuk instrumen angket post test sebesar 0,773 dan nilai ini lebih besar dari alpha yaitu 0,5 dimana $0,773>0,6$. Dengan demikian, instrumen post test tersebut telah memenuhi syarat reliabel dan dapat digunakan untuk penelitian.

\section{Analisis Deskriptif}

Deskripsi data hasil penelitian meliputi data pre test dan data post test angket. Nilai pre test adalah skor awal hasil belajar siswa, sedangkan nilai post test adalah skor akhir hasil belajar siswa. Untuk mengetahui pengaruh model pembelajaran yang digunakan, dapat dilihat dari mean (nilai rata-rata) dan modus (nilai yang sering muncul) hasil belajar.

Penghitungan nilai pretest dapat kita lihat pada tabel 3 berikut ini;
Tabel 3 Rangkuman Distribusi Frekuensi Pretest

\begin{tabular}{lrr}
\hline \multicolumn{2}{c}{ Statistics } \\
\hline Nilai_Pretest & \\
\hline $\mathrm{N}$ & Valid & 10 \\
\cline { 2 - 3 } & Missing & 0 \\
\hline Mean & 59.00 \\
Median & 59.00 \\
Mode & 61 \\
Std. Deviation & 4.055 \\
Minimum & 53 \\
Maximum & 67 \\
Sum & 590 \\
\hline
\end{tabular}

Berdasarkan tabel 3 diatas, hasil pre test siswa diperoleh modus adalah 61 . Adapun mean pre test siswa adalah 59,00.

Tabel 4. Rangkuman Distribusi Frekuensi Posttest

\begin{tabular}{|c|c|c|}
\hline \multicolumn{3}{|c|}{ Statistics } \\
\hline \multicolumn{3}{|c|}{ Nilai_Posttest } \\
\hline \multirow[t]{2}{*}{$N$} & Valid & 10 \\
\hline & Missing & 0 \\
\hline \multicolumn{2}{|c|}{ Mean } & 88.10 \\
\hline \multicolumn{2}{|c|}{ Median } & 87.50 \\
\hline \multicolumn{2}{|c|}{ Mode } & 86 \\
\hline \multicolumn{2}{|c|}{ Std. Deviation } & 4.408 \\
\hline \multicolumn{2}{|c|}{ Minimum } & 81 \\
\hline \multicolumn{2}{|c|}{ Maximum } & 96 \\
\hline \multicolumn{2}{|c|}{ Sum } & 881 \\
\hline
\end{tabular}

Berdasarkan tabel diatas, hasil post test siswa diperoleh modus adalah 86. Adapun mean post test siswa adalah 88,10 .

Uji Normalitas digunakan untuk mengetahui apakah ada data yang diperoleh dari masing-masing variabel berdistribusi normal atau tidak. Perhitungan dalam uji normalitas menggunakan rumus ShapiroWilk dengan taraf signifikan 0,05. Seluruh proses perhitungan dilakukan dengan bantuan komputer program SPSS V16. Kriteria yang digunakan adalah jika hasil $\mathrm{p}>$ 0,05 maka distribusi frekuensi tersebut normal, sebaliknya jika hasil $\mathrm{p}<0,05$ maka distribusi frekuensi tidak normal. Untuk memperoleh hasil uji normalitas, digunakan data nilai pretest dan posttest siswa, 
kemudian data diolah menggunakan aplikasi SPSS V16. Berikut ini rangkuman hasil uji normalitas data dari angket.

Tabel 5. Output Uji Normalitas

\begin{tabular}{|c|c|c|c|}
\hline \multicolumn{4}{|c|}{ Tests of Normality } \\
\hline & \multicolumn{3}{|c|}{ Shapiro-Wilk } \\
\hline & Statistic & $\mathrm{df}$ & Sig. \\
\hline Nilai_Pretest & .969 & 10 & .885 \\
\hline Nilai_Posttest & .968 & 10 & .873 \\
\hline
\end{tabular}

Berdasarkan data dari tabel 5, dapat diperoleh hasil bahwa nilai Shapiro-Wilk pada Pre-Test 0,969 dengan Sig 0,885 ini berarti data Pre-Test tersebut berdistribusi normal dan nilai Shapiro-Wilk pada PostTest 0,968 dengan sig 0,873 yang berarti data Post-Test berdistribusi normal. Dari data tersebut dapat dilihat bahwa Asymp Sig (2tailed) distribusi data yang diperoleh lebih besar dari $\alpha=0,05$. Dapat disimpulkan bahwa Asymp Sig (2-tailed) distribusi data Pre-Test dan Post-Test pada masing-masing variabel normal sehingga dapat digunakan untuk uji hipotesis.

Uji One Sample T-Tes digunakan untuk mengetahui apakah ada Pengaruh Model Discovery Learning terhadap Keaktifan Siswa dalam Pembelajaran IPA Kelas IV SD YPK Persiapan Mirafan.

Hipotesis dalam penelitian ini adalah; H1 di terima jika signifikan $<0,05$ dan Thitung > Ttabel. H0 ditolak jika signifikan $>0,05$ dan Thitung < Ttabel.

$\mathrm{H}_{1}$ : Ada Pengaruh Model Discovery Learning terhadap Keaktifan Siswa dalam Pembelajaran IPA Kelas IV SD YPK Persiapan Mirafan.

$\mathrm{H}_{0}$ : Tidak ada Pengaruh Model Discovery Learning terhadap Keaktifan Siswa dalam Pembelajaran IPA Kelas IV SD YPK Persiapan Mirafan.

Kriteria yang digunakan apabila nilai $\mathrm{T}_{\text {hitung }}>\mathrm{T}_{\text {tabel }}$ atau sig $<0,05$ maka $\mathrm{H}_{1}$ diterima dan $\mathrm{H}_{0}$ ditolak yang berarti Model
Discovery Learning memiliki pengaruh terhadap Keaktifan Siswa. Sedangkan apabila nilai $t_{\text {hitung }}<$ dari $t_{\text {tabel }}$ atau sig $>$ dari 0,05 maka $\mathrm{H}_{1}$ di tolak dan $\mathrm{H}_{0}$ diterima yang berarti Model Discovery Learning tidak memiliki pengaruh terhadap Keaktifan Siswa SD YPK Persiapan Mirafan. Hasil analisis selengkapnya dapat di lihat dari lampiran, sedangkan rangkuman hasil analisis di sajikan pada tabel berikut:

Tabel 6. Output Uji One-Sample Test

\begin{tabular}{lrrrr}
\hline \multicolumn{3}{c}{ One-Sample Test } \\
\cline { 2 - 4 } & t & df & Sig. (2-tailed) \\
Keaktifan Siswa & 12.984 & 9 & .000
\end{tabular}

Pengambilan keputusan berdasarkan nilai Sig.(2-tailed). Berdasrkan tabel 6, di ketahui bahwa nilai Sig.(2-tailed) sebesar 0,000 dan nilai $0,000<0,005$, maka dapat di simpulkan bahwa pembelajaran dengan Doscovery Learning memiliki pengaruh terhadap Keaktifan Siswa kelas IV SD YPK Persiapan Mirafan.

Pengambilan keputusan berdasarkan nilai uji T-Tes

Berdasarkan tabel 6 hasil Uji One Sample T-Test menunjukan bahwa nilai $\mathrm{t}$ hitung sebesar 12,984. Selanjutnya adalah tahap mencari t tabel, dimana t tabel di cari berdasarkan nilai df (degree of freedom atau derajat kebebasan) dan nilai signifikansi $(\alpha / 2)$. Dari data di atas di ketahui nilai df adalah $n-1$ yaitu $10-1=9$ dan nilai $0,05 / 2=$ 0,025 . Nilai tersebut di gunakan sebagai dasar acuan dalam mencari nilai t tabel pada distibusi nilai $\mathrm{t}$ tabel statistik (terlampir), maka nilai t tabel sebesar 2,262.

Berdasarkan hasil penelitian yang dilakukan di SD YPK Persiapan Mirafan, sampel yang digunakan untuk penelitian ini adalah siswa kelas IV dengan jumlah 10 
siswa. Penelitian ini merupakan penelitian eksperimen oleh sebab itu sebelum responden diberi perlakuan terlebih dahulu diberikan pre-test untuk melihat hasil awal keaktifan siswa, setelah itu siswa diberi perlakuan yaitu model discovery learning. Setelah perlakuan selesai siswa diberikan post-test untuk melihat hasil apakah ada pengaruh dari perlakuan. Dari hasil pre-test diperoleh hasil mean sebesar 59,00 dan hasil mean post-test sebesar 88,10.

Mengolah data dengan melakukan uji prasyarat terlebih dahulu yaitu dengan melakukan uji normalitas data, berdasarkan pengolahan data uji normalitas menggunakan aplikasi SPSS 16.0 diperoleh hasil signifikasi data pre-test sebesar 0,885 dan 0,885>0,05 berarti data pre-test berdistribusi normal, sedangkan data post-test diperoleh hasil sebesar 0,873 dan $0,873>0,05$ sehingga post-test berdistribusi normal. Kedua data berdistribusi normal maka dapat melakukan uji selanjutnya yaitu uji hipotesis. Uji hipotesis dilakukan dengan uji one sampel ttest.

Hasil uji One Sample T-Test diperoleh hasil t hitung sebesar 12,984 nilai df pada penelitian $\mathrm{n}-1$ yaitu $10-1=9$, nilai df 9 adalah 2,262 jadi $\mathrm{t}$ hitung $>\mathrm{t}$ tabel yaitu $12,984>2,262$. Dari hasil uji one sampel ttest menunjukkan bahwa $\mathrm{H} 1$ diterima dan $\mathrm{H} 0$ ditolak artinya ada Pengaruh Model Discovery Learning terhadap Keaktifan Siswa dalam Pembelajaran IPA Kelas IV SD YPK Persiapan Mirafan.

\section{KESIMPULAN}

Berdasarkan rumusan masalah dan hipotesis yang diajukan, hasil analisis hipotesis dan pembahasan penelitian eksperimen pada Keaktifan Siswa dengan Model Discovery Learning pada Pembelajaran IPA Kelas IV SD YPK
Persiapan Mirafan maka dapat dikemukakan kesimpulan penelitian sebagai berikut:

Terdapat perbedaan mean (nilai ratarata) antara nilai pre-test dan post-test. Dari perhitungan diperoleh nilai mean pre-test sebesar 59,00 dan nilai mean post-test sebesar 88,10 berdasarkan nilai pre-test dan nilai post-test ini dapat diambil kesimpulan bahwa dengan model discovery learning dapat mempengaruhi keaktifan siswa.

Model Discovery Learning memiliki pengaruh terhadap keaktifan siswa SD YPK Persiapan Mirafan. Dari perhitungan One Sampel t-test diperoleh $\mathrm{t}$ hitung $>$ ttabel yaitu 12,984 > 2,262 Sehingga dapat disimpulkan bahwa H0 ditolak dan H1 diterima atau model discovery learning memberi pengaruh terhadap keaktifan siswa menjadi meningkat.

\section{DAFTAR RUJUKAN}

Anni, Catharina Tri. 2009. Psikologi Belajar. Semarang : UNNES

Arikunto, Suharsimi, dan Suhardjono dan Supardi. 2013. Penelitian Tindakan Kelas. Jakarta: PT. Bumi Aksara. 2009. Penelitian Tindakan Kelas. Jakarta: PT. Bumi Aksara.

Asrul, A., Ridlo, S., \& Susilo, S. (2018). Creative Thinking Analysis, Motivation and Concept Mastery on Learning of Cooperative Discovery Model in Elementary School. Journal of Primary Education, 7(1), 48-56.

Budiasa, P., \& Gading, I. K. (2020). Model pembelajaran Inkuiri terbimbing berbantuan media gambar terhadap keaktifan dan hasil belajar IPA. Mimbar PGSD Undiksha, 8(2), 253-263.

Dimyati dan Mujiono. 2010. Belajar dan pembelajaran, Jakarta : Rineka Cipta.

Depdiknas. 2015. Peraturan Menteri Pendidikan Nasional No. 22 tahun 2006 tentang Standar Isi Satuan Pendidikan. Jakarta: Depdiknas. 2008

Hassibuan, JJ dan Mudjiono.2012. Proses Belajar Mengajar. Bandung : PT. Remaja Rosdakarya.

Ihsan, Fuad. 2011. Dasar-dasar Kependidikan 
Komponen MKDK. Jakarta: Rineka Cipta. Johnson dan Johnson, 1996. Cooperative Learning Two Heads Learn Better Than One. Http/www.contexs.org./elib/c.18/ Johnson. Htm.

Oemar Hamalik. 2009. Proses belajar mengajar. Bandung: Bumi Aksara.

2010. Proses belajar mengajar. Bandung: Bumi Aksara.

Purnomo Sudjino, Trijoko, Suwarno, Hadi Susanto. 2009. Biologi Kelas XI untuk SMA dan MA. Pusat Perbukuan Depertemen Pendidikan Nasional.

Purwanto. 2011. Evaluasi Hasil Belajar. Yogyakarta: Pustaka Pelajar

Purwanto, Ngalim. 2011. Psikologi Pendidikan. Bandung: Alfa Beta.

Putrayasa, I. M., Syahruddin, S. P., \& Margunayasa, I. G. (2014). Pengaruh model pembelajaran discovery learning dan minat belajar terhadap hasil belajar IPA siswa. Mimbar PGSD Undiksha, 2(1).

Poerwadarminta, W.J.S., 2014, Kamus Bahasa Indonesia. Pusat Bahasa, Departemen Pendidikan Nasional. Edisi III Cetakan kedua. Jakarta: Balai Pustaka.

Riyanto. (2009). Paradigma Baru Pembalajaran. Jakarta: Kencana prenada media grup

Rustaman, N. 2010. Strategi belajar mengajar biologi. Malang: UM Press

Sagala, Syaiful.2011. Konsep dan Makna Pembelajaran. Bandung: Alfa Beta

Salo, Y. A. (2017). Pengaruh Metode Discovery
Learning Terhadap Keaktifan Belajar Siswa (Studi Quasi Eksperimen Kelas VII SMPN 6 Banda Aceh). Jurnal Penelitian Pendidikan, 16(3), 297-304.

Sardiman, A. M. 2004. Interaksi dan Motivasi Belajar Mengajar. Jakarta : Rajawali Press.

Sanjaya, Wina. (2010). Strategi Pembelajaran Berorientasi Standar Proses Pendidikan. Jakarta : Prenada Media Group.

Sanjaya, Wina. 2012. Strategi Pembelajaran. Jakarta: Media Prenada.

Slavin Robert E. 2015. Cooperative Learning: Teori, Riset dan Praktik. Bandung: Nusa Media.

Suprijono, Agus. 2011. Cooperative Learning Teori dan Aplikasi PIKEM. Yogyakarta: Pustaka Belajar.

Subyantoro. 2009. Penelitian Tindakan Kelas. Semarang : CV. Widya Karya.

Suprijono, Agus, 2009, Cooperative Learning: Teori dan Aplikasi PAIKEM, Yogyakarta: Pustaka Pelajar.

Trianto. 2012. Model Pembelajaran Terpadu. (Jakarta:PT Bumi Aksara)

Wenno, I. H., Wattimena, H. S., Watuguly, Th. W. (2009).Penelitian dan Pengem-bangan Model Modul (LKS Eksperimen dan LKS non Eksperimen Berbasis Problem Solving Method)di SMP Se Provinsi Maluku. Penelitian Hibah Bersa-ing Dikti 20072009.

Winataputra, Udin S., 2010. Teori Belajar dan Pembelajaran. Jakarta: Universitas Terbuka. 